\title{
Characterization and Investigation of Stigmasterol Isolated from Rodent Tuber Mutant Plant (Typhonium flagelliforme), Its Mo- lecular Docking as Anticancer on MF-7 Cells
}

\author{
Nesti Fronika Sianipar1,2,*, Yuni Elsa Hadisaputri ${ }^{3,4}$, Khoirunnisa Assidqii ${ }^{1,2}$, Supriatno Salam ${ }^{5,6}$, Muhammad Yusuf ${ }^{5}$, \\ Wanda Destiarani ${ }^{5}$, Ragapadmi Purnamaningsih ${ }^{7}$, Idris Gautama So $^{8}$
}

\begin{abstract}
${ }^{1}$ Food Technology Department, Faculty of Engineering, Bina Nusantara University, 11480 Jakarta, Indonesia ${ }^{2}$ Research Interest Group Food Biotechnology, Bina Nusantara University, 11480 Jakarta, Indonesia

${ }^{3}$ Department of Biological Pharmacy, Faculty of Pharmacy, Universitas Padjadjaran, 45363 Sumedang, Jl. Bandung Sumedang Km 21, Jatinangor, 45363, Indonesia

${ }^{4}$ Biological Activity Division, Central Laboratory, Universitas Padjadjaran, Jl. Bandung Sumedang Km 21, Jatinangor, 45363, Indonesia

${ }^{5}$ Department of Chemistry, Faculty of Mathematics and Natural Sciences, Universitas Padjadjaran, Jl. Bandung Sumedang Km 21 Jatinangor, 45363, Indonesia.

${ }^{6}$ Faculty of Pharmacy, Universitas Mulawarman, Samarinda 75123, Kalimantan Timur, Indonesia.

${ }^{7}$ Indonesian Center for Agricultural Biotechnology and Genetic Resources Research and Development (BB-Biogen), 16111 Bogor, Indonesia

${ }^{8}$ Management Department, Binus Business School, Undergraduate Program, Bina Nusantara University, Jakarta 11480, Indonesia

*Correspondence: nsianipar@binus.edu; Tel.: +62 81315797433
\end{abstract}

\begin{abstract}
Typhonium flagelliforme is an Indonesian herbal plant used and applied traditionally to treat cancer diseases. Gamma rays have irradiated rodent tuber mutant plant at six doses gray to increase the chemical compounds of anticancer activity. The effect of isolated compounds from rodent tuber mutant plants has never been studied and published yet. Our study unveiled the potential of stigmasterol as a remarkable cytotoxic agent and the significant contribution of NMR spectroscopy, IR, Mass spectra, QTOF MS towards the isolation and identification of this anticancer agent. Stigmasterol was isolated from T. flagelliforme mutant plant. Stigmasterol was more effective against MCF-7 cells with an IC 50 value of $0.1623 \mu \mathrm{M}$ than Cisplatin with IC 50 value $13.2 \mu \mathrm{M}$. It is the most potential and active fraction in the human breast cancer cell line. The molecular docking study analyzed the chemical profile of stigmasterol to confirm the receptor in agonist binding sites. The prediction of the toxicity of stigmasterol compounds using in silico and analysis of its interaction with the receptor can act as a competitive regulator with a high-affinity binding site on FXR. Stigmasterol has potential as a candidate for an anticancer drug that promoting further clinical action.
\end{abstract}

Keywords: Typhonium flagelliforme, MCF-7 cell line, stigmasterol, agonistic, mutant plant

\section{Introduction}

Rodent tuber with latin name Typhonium flagelliforme, known as a local name in Indonesia, belongs to the Araceae family. T. flagelliforme is a herbal plant from Indonesia that plays an active role in anticancer activity in various cancer cell lines, including lung and breast cancer cells [1], T4-lymphoblastoid leukemia [2], T47D breast [3], MCF-7 breast [4]. Gamma rays successfully irradiated T. flagelliforme plants through combined mutagenesis of somaclonal variations in vitro to increase the number of bioactive compounds contained therein. T. flagelliforme mutant plants have been detected to undergo genetic changes in the first generation (MV1) [5]. The second-generation (MV2) and third-generation (MV3) T. flagelliforme mutants have shown genetic changes through molecular RAPD by comparing wild-type [6]. T. flagelliforme mutant plant received Plant Variety Protection by the Indonesian Ministry of Agriculture in 2020. T. flagelliforme mutant plant has been shown to have 
bioactive compounds, and its potential as an anticancer agent has increased [6-8]. The ethyl acetate fraction of the superior T. flagelliforme mutant has potential as an anticancer with an $\mathrm{IC}_{50}$ value of $1.09 \mu \mathrm{g} / \mathrm{mL}$. In comparison, the ethanol extract has an $\mathrm{IC}_{50}$ value of 1.60 $\mu \mathrm{g} / \mathrm{mL}$ [9]. This indicated that the cytotoxic activity of T. flagelliforme mutant extract was three times more effective than wild-type extract, with an $\mathrm{IC}_{50}$ value of $19.11 \mu \mathrm{g} / \mathrm{mL}$ [8].

Based on the GC-MS analysis of the chemical components of the KB 6-3-3-6 T. flagelliforme mutant plant extract, it was found that hexadecenoic acid, octadecadienoic acid, stigmasterol, and beta-sitosterol compounds were more significant in quantity than wild type [10]. The stigmasterol compound can be an antioxidant and reduces Ehrich Ascite Carcinoma (EAC) by reducing lipid peroxidation and increasing catalase in the liver of EAC rats [11]. Stigmasterol is the main phytosterol in various herbal plants with anti-inflammatory properties and anticancer agents [12]. Stigmasterol can inhibit the growth of uterine cancer cells ES2 and OV90 by $50 \%$ at a treatment concentration of $20 \mu \mathrm{g} / \mathrm{mL}$ [13]. However, the molecular mechanism of stigmasterol compounds isolated from T. flagelliforme mutant plants has not yet been revealed on breast cancer cell death (MCF-7 cell line).

In silico methods, such as molecular docking, have been used to predict the molecular mechanism of bioactive compounds at the atomic level [14-16]. Therefore, in this work, we also explored the anti-breast cancer activity of the isolated compound using the molecular docking method. Molecular docking is critical in the planning and layout of new drugs. The aim of having a compulsory experimental mode and small molecule affinity within the binding site of the desired target receptor. A successful splicing methodology must correctly predict the native ligand to which the receptor binds and the associated physicochemical molecular interactions [17]. In this study aims, stigmasterol compound was selected to characterize the anticancer activity and examine the pathway expression mechanisms in vitro through an in silico evaluation using molecular docking studies to explore the binding mode and its interaction with the MCF-7 breast cancer cell line.

\section{Materials and Methods}

\subsection{Plant Material}

T. flagelliforme mutant plant KB 6-3-3-6 was collected from Sianipar \& Purnamaningsih's collection. It has been irradiated by gamma-ray with a dose of 6 Gy to produce in vitro mutagenesis and obtained as mutant plants. The mutant plant was acclimatized and maintained at Indonesian Center for Agricultural Biotechnology and Genetic Resources Research and Development, Ministry of Agriculture, Bogor, Indonesia.

\subsection{Extraction and Isolation}

The tubers of T. flagelliforme mutant KB 6-3-3-6 were harvested and dried into a powder. T. flagelliforme mutant plant powder was submerged in ethanol $96 \%$ and repeatedly macerated seven times until the extract indicated colorless. The solvents were evaporated using a rotary evaporator (Rotavapor ${ }^{\circledR} \mathrm{R}-300$, Buchi) at $50^{\circ} \mathrm{C}$. The highly concentrated ethanol extract was obtained. Extracting ethyl acetate separation was chosen using the KCV method to use vacuum assistance to make it faster and the separation more efficient. Separation with $\mathrm{KCV}$ is based on the principle of adsorption with the adsorbent as the stationary phase used is silica gel G60 (70-230 mesh) with n-hexane- ethyl acetate-methanol solvent system about 10\% gradient. The results of KCV of ethyl acetate extract obtained 21 fractions, and each fraction was analyzed by TLC on a GF 254 silica plate eluted with nhexane: ethyl acetate (1:1) to determine the staining pattern of the compounds contained in each fraction of the separation results. Sub-fraction was obtained and separated by column chromatography on silica gel (70-230 mesh) with a gradient $n$-hexane-methylene chloride-ethyl acetate about $5 \%$ solvent system. The combined sub-fraction was collected 
and separated by column chromatography on silica gel (230-400 mesh) with a solvent system of $n$-hexane-methylene chloride-isocratic ethyl acetate $(6: 2.5: 1.5)$, then obtained compound 1 as yellow solid $(4.8 \mathrm{mg})$.

\subsection{Characterization of Chemical Structures from the Mutant Plant}

The IR spectra and mass spectra were recorded on a SHIMADZU IR Prestige-21 in KBr and Waters Xevo QTOF MS using an NMR JEOL ECZ-500 and Variant Unity INOVA500 Spectrometer (Agilent Technologies, Santa Carla, United States). The NMR data were recorded at $500 \mathrm{MHz}$ for ${ }^{1} \mathrm{H}$ and $125 \mathrm{MHz}$ for ${ }^{13} \mathrm{C}$, using TMS as internal standard. Column chromatography was conducted on the silica gel 60 (70-230 and 230-400 mesh, Merck), after which TLC analysis was carried out on 60 GF 254 (Merck, $0.25 \mathrm{~mm}$ ) using various solvent systems to detect spots by irradiating under ultraviolet-visible light (257 and $364 \mathrm{~nm}$ ) and heating of silica gel plates, sprayed with $\mathrm{H}_{2} \mathrm{SO}_{4}$ in $\mathrm{EtOH}(10 \%)$.

\subsection{Cell Viability Evaluation by PrestoBlue Assay}

Cell viability of MCF-7 breast cancer cells was performed by the PrestoBlue assay method. MCF-7 cells were purchased from American Type Cell Cancer (Manassas, VA, US) that cultured in Eagle's Minimum Essential Medium (EMEM) medium (Sigma Aldrich; Merck KGaA, Darmstadt, German) contained 10\% Fetal Bovine Serum (FBS) (Sigma Aldrich; Merck KGaA) and 1\% of $100 \mu \mathrm{g} / \mathrm{ml}$ penicillin and $100 \mu \mathrm{g} / \mathrm{ml}$ streptomycin (Sigma Aldrich; Merck KGaA). Cisplatin (Sigma Aldrich; Merck KGaA) was used as a positive control. Each well of 96 well plates contained the cells to be tested with cultured medium replacement. $100 \mu \mathrm{L}$ of medium containing stigmasterol from T. flagelliforme superior mutant with serial concentration obtained 2423.05, 1211.52, 605.76, 302.88, 151.440,75.72, 37.86, $18,92 \mu \mathrm{M}$ of test solution. The amount of $100 \mu \mathrm{l}$ of PrestoBlue solution (Invitrogen; Thermo Fisher Scientific, Waltham, MA, US) (10\% in medium without FBS) was added to each well plate incubated at $37^{\circ} \mathrm{C}$ and $5 \% \mathrm{CO}_{2}$ gas for $24 \mathrm{~h}$. The change in the fluorescence of the test reagent (resazurin to resorufin) was measured using an Infinite M200 PRO microplate reader (Tecan, Männedorf, Switzerland) with the excitation wavelengths set at 570/600 nm. The conversion value is proportional to the number of metabolically active cells and can be measured quantitatively. The percentage of cell viability equals (absorbance of treated cells/absorbance of untreated cells) $\times 100 \%$. The morphological features were captured using by microscope EVOS XL Core Imaging System (Invitrogen; Thermo Fisher Scientific).

\subsection{In Silico Bioprospection of Stigmasterol}

The crystal structure of natural ligand and agonist ligand binding with Farsenoid X Receptor (FXR) was downloaded from the PDB library (PDB ID: 7D42 and 1OT7) [18],[19]. The ligands structure was separated from the receptor using Discovery Studio 2021, the water molecules and heteroatoms were also removed. Chem3D modeled the 3D structure of stigmasterol. Docking simulation with a rigid receptor structure was performed with AutoDock 4.2.6 [20]. Furthermore, the 3D structure of stigmasterol was converted into the PDBQT format by employing the Gasteiger charges and adding the atom types using AutoDock Tools 1.5.6. The size of the grid box of the receptor was $40 \times 40 \times 50$ points with a grid spacing of $0.375 \AA$, centered in the binding site of the ligand. The Lamarckian Genetic algorithm was used with the following parameters: trials of 100 runs, energy evaluations of 2,500,000, and population size of 150. The energy breakdown analysis and ligand efficiency (total binding energy divided by a number of atoms) were also calculated. The docking result was visualized using Biovia Discovery Studio Visualizer and sorted based on 
the free energy of binding on the most populated cluster and their intermolecular interactions.

\section{Results and Discussion}

\subsection{Chemical Structure Characterization}

The fraction ethyl acetate from the dry powder of tubers T. flagelliforme was chromatographed over a vacuum-liquid chromatographed (VLC) column, packed with silica gel 60 by gradient elution. The VLC fractions were repeatedly subjected to standard and reversed-phase column chromatography and preparative TLC on silica gel GF 254 to accommodate compounds 1 .

Stigmasterol (1) was observed as a colorless amorphous solid, with its molecular composition established as $\mathrm{C}_{29} \mathrm{H}_{48} \mathrm{O}_{2}$, based on HR-TOFMS. This showed a $[\mathrm{M}+\mathrm{H}]+$ ion peak at $\mathrm{m} / \mathrm{z} 429.3654$ (calcd. $\mathrm{C}_{29} \mathrm{H}_{49} \mathrm{O}_{2} \mathrm{~m} / \mathrm{z}$ 429.3650), requiring to six degrees of unsaturation. The IR spectrum showed bands which were ascribed to a hydroxyl $\left(v_{\max } 3495 \mathrm{~cm}^{-1}\right.$. Furthermore, the ${ }^{1} \mathrm{H}-\mathrm{NMR}$ spectrum (Table 1$)$ showed six primary methyls at $\delta \mathrm{H} 0.68(3 \mathrm{H}$, s, H-18), 0.85 (3H, t, H-29), 0.81 (3H, d, H-27), 0.84 (3H, d, H-26), 0.92 (3H, d, H-21) and 1.00 $(3 \mathrm{H}, \mathrm{s}, \mathrm{H}-19)$ which indicates the characteristics of the compounds within the phytosterol group steroid framework [21]. Nine methylene protons $s p^{3}$ at $\delta \mathrm{H} 1.51(2 \mathrm{H}, \mathrm{H}-11), 1.27(2 \mathrm{H}$, H-28), 1.13; 1.61 (2H, H-15), 1.35; 1.86 (2H, H-16), 1.85; 1.56 (2H, H-2), 1.53 (2H, H-7), 1.15; $1.89(2 \mathrm{H}, \mathrm{H}-1), 1.19 ; 2.03(2 \mathrm{H}, \mathrm{H}-12)$ and $2.28(2 \mathrm{H} . \mathrm{H}-4)$ and there are seven metine protons $s p^{3}$ at $\delta_{\mathrm{H}} 1.71(1 \mathrm{H}, \mathrm{H}-25), 1.91(1 \mathrm{H}, \mathrm{H}-8), 1.37$ (1H, H-20), 0.97 (1H, H-24), 0.98 (1H, H-9), 1.10 $(1 \mathrm{H}, \mathrm{H}-17)$ and $1.00(1 \mathrm{H}, \mathrm{H}-14)$, one oxygenated methine proton at $\delta_{\mathrm{H}} 3.53(1 \mathrm{H}, m, \mathrm{H}-3)$ and three methine protons $s p^{2}$ at $\delta \mathrm{H} 5.36(1 \mathrm{H}, \mathrm{dd}, 2.5 ; 7.2 \mathrm{H}-6), 4.97(1 \mathrm{H}, \mathrm{dd}, 5.5 ; 14.2, \mathrm{H}-22)$ dan $5,11(1 \mathrm{H}, \mathrm{dd}, 4.5 ; 14.2, \mathrm{H}-23)$ indicated olefinic binding to C-22 and C-23 is trans.

The ${ }^{13} \mathrm{C}$ NMR (Table 1) together with the DEPT spectra revealed twenty-nine carbons consisting of an six methyl carbon signals on $\delta c 11.9$ (C-18), 11.9 (C-29), 18.9 (C-27), 19.0 (C-26), 19.5 (C-21), and 19.7 (C-19), nine methylene carbon $s p^{3}$ at $\delta c 21.2$ (C-11), 23.2 (C-28), 24.4 (C-15), 28.4 (C-16), 31.7 (C-2), 31.9 (C-7), 37.3 (C-1), 39.9 (C-12) and 42.5 (C-4) and there are seven metine carbons $s p^{3}$ at $\delta c 29.2$ (C-25), 31.9 (C-8), 36.4 (C-20), 45.9 (C-24), 50.2 (C-9), 56.0 (C-17), 56.8 (C-14), one oxygenated metine carbon at $\delta c 71.9$ (C-3), three metine carbons $s p^{2}$ at $\delta c 121.9(\mathrm{C}-6), 129.4$ (C-22) dan 138.5 (C-23), two quaternary carbon $s p^{3}$ at $\delta c$ 36.6 (C-10), 42.4 (C-13) and one quaternary carbon $s p^{2}$ at $\delta c 140.9$ (C-5).

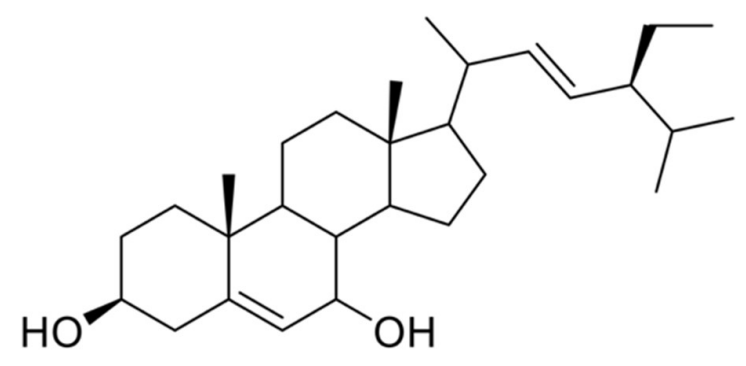

Figure 1. Structures of stigmasterol (1). 
Table 1. NMR data compound 1 (500 MHz for ${ }^{1} \mathrm{H}$ dan $125 \mathrm{MHz}$ for ${ }^{13} \mathrm{C}$ ).

\begin{tabular}{|c|c|c|}
\hline Position Carbon & ${ }^{13} \mathrm{C}-\mathrm{NMR} \delta \mathrm{c} / \mathrm{ppm}$ & ${ }^{1} \mathrm{H}-\mathrm{NMR} \delta \mathrm{H}\left(\sum \mathrm{H}\right.$, Mult, $\left.\mathrm{J} / \mathrm{Hz}\right)$ \\
\hline 1 & 37,3 & 1,$15 ; 1,89(2 \mathrm{H}, \mathrm{m})$ \\
\hline 2 & 31,7 & 1,$85 ; 1,56(2 \mathrm{H}, \mathrm{m})$ \\
\hline 3 & 71,9 & $3,53(1 \mathrm{H}, \mathrm{m})$ \\
\hline 4 & 42.5 & $2,28(2 \mathrm{H}, \mathrm{m})$ \\
\hline 5 & 140,9 & - \\
\hline 6 & 121,9 & $5,36(1 \mathrm{H}, \mathrm{dd}, 2,5 ; 7,2)$ \\
\hline 7 & 31,9 & $1,53(2 \mathrm{H}, \mathrm{m})$ \\
\hline 8 & 31,9 & $1,93(1 \mathrm{H}, \mathrm{m})$ \\
\hline 9 & 50,2 & $0,98(1 \mathrm{H}, \mathrm{m})$ \\
\hline 10 & 36.6 & - \\
\hline 11 & 21,2 & $1,51(2 \mathrm{H}, \mathrm{m})$ \\
\hline 12 & 39.9 & 1,$19 ; 2,03(2 \mathrm{H}, \mathrm{m})$ \\
\hline 13 & 42,4 & - \\
\hline 14 & 56,8 & $1,00(1 \mathrm{H}, \mathrm{m})$ \\
\hline 15 & 24.4 & 1,$13 ; 1,61(2 \mathrm{H}, \mathrm{m})$ \\
\hline 16 & 28.4 & 1,$35 ; 1,86(2 \mathrm{H}, \mathrm{m})$ \\
\hline 17 & 56.0 & $1,10(1 \mathrm{H}, \mathrm{m})$ \\
\hline 18 & 11,9 & $0,68(3 \mathrm{H}, \mathrm{s})$ \\
\hline 19 & 19,7 & $1,00(3 \mathrm{H}, \mathrm{s})$ \\
\hline 20 & 36,4 & $1,37(1 \mathrm{H}, \mathrm{m})$ \\
\hline 21 & 19,5 & $0,92(3 \mathrm{H}, \mathrm{d}, 7)$ \\
\hline 22 & 129,4 & $4,97(1 \mathrm{H}, \mathrm{dd}, 5,5 ; 14,2)$ \\
\hline 23 & 138,5 & $5,11(1 \mathrm{H}, \mathrm{dd}, 2,5 ; 14,2)$ \\
\hline 24 & 45.9 & $0,97(1 \mathrm{H}, \mathrm{m})$ \\
\hline 25 & 29.2 & $1,70(1 \mathrm{H}, \mathrm{m})$ \\
\hline 26 & 19,0 & $0,84(3 \mathrm{H}, \mathrm{d}, 7)$ \\
\hline 27 & 18,9 & $0,82(3 \mathrm{H}, \mathrm{d}, 7)$ \\
\hline 28 & 23.2 & $1,27(2 \mathrm{H}, \mathrm{m})$ \\
\hline 29 & 11,9 & $0,85(3 \mathrm{H}, \mathrm{t}, 7)$ \\
\hline
\end{tabular}

\subsection{Cytotoxicity of Stigmasterol on MCF-7 Cell Line}

Effects of the T. flagelliforme mutant plant isolate known as stigmasterol have inhibition activity against breast cancer MCF-7 cell line at $24 \mathrm{~h}$. The minimum concentration of the extract giving a $50 \%$ inhibition ( $\mathrm{IC}_{50}$ ) was about $0.1623 \mu \mathrm{M}$ (Fig. 4). Stigmasterol showed to be the most active and potential, comparing favorably with Cisplatin about $13.2 \mu \mathrm{M}$ [22]. Based on the IC50 value of stigmasterol showed the most robust cytotoxic activity on MCF-7 cell lines. The morphological cytotoxic activity was expressed as a percentage of cell viability in MCF-7 cell lines (Fig. 5). Observation of MCF7 cells after treatment with stigmasterol for 24 hours showed slow cell proliferation. Furthermore, decreasing cells revealed that treatment at $605.76 \mathrm{M}$ compared to control (DMSO) decreased the ability to adhere to MCF-7 breast cancer cell lines. The significant 
anticancer effect of the T. flagelliforme mutant plant is maybe due to the presence of the isolated bioactive compound of stigmasterol from the extract.

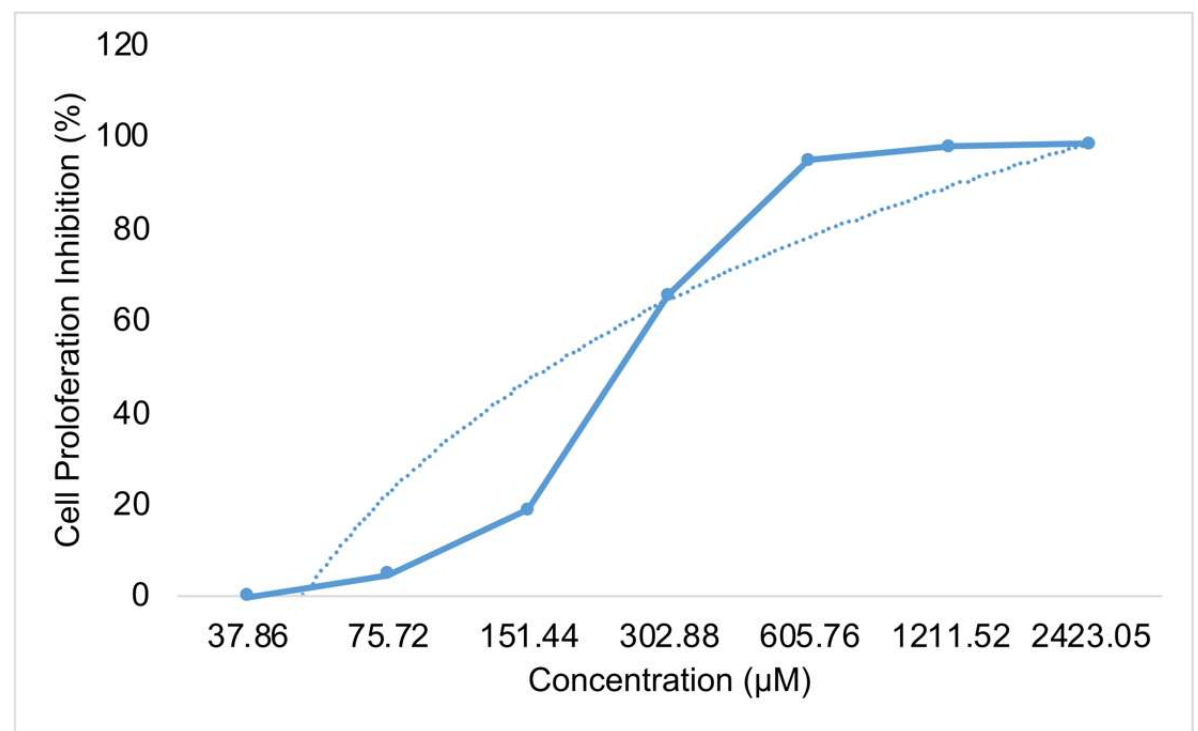

Figure 2 The percentage of cell proliferation inhibition of stigmasterol from rodent tuber mutant plant isolate on the viability of breast cancer cell MCF-7 for $24 \mathrm{~h}$.

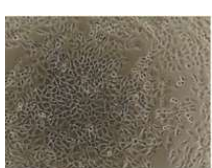

$75.72 \mu \mathrm{M}$

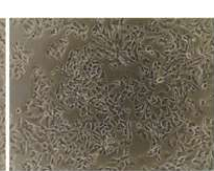

$151.44 \mu \mathrm{M}$

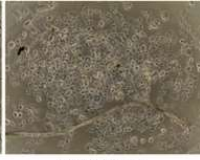

$302.88 \mu \mathrm{M}$

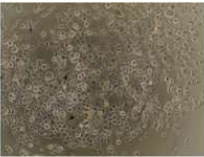

$605.76 \mu \mathrm{M}$

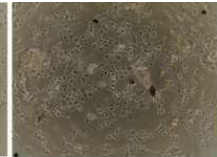

$1211.52 \mu \mathrm{M}$

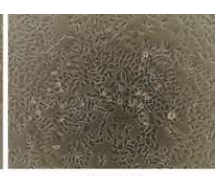

Control

Figure 3 The morphology of MCF-7 cells exposed to stigmasterol isolate at each concentrations.

Al-Fatlawi [23] reported that stigmasterol exerts anti-proliferative activities against the human cancerous breast MCF-7 cancer line with the IC50 value of about 27.38 $\mu \mathrm{M}$. The cytotoxicity concentration of stigmasterol evaluated against MCF-7 cell line with IC50 value was $14.5 \mu \mathrm{g} / \mathrm{mL}$ from Kopsia singapuraensis Ridl. [24]. In another study, cytotoxicity stigmasterol isolated from Polygonum hydropiper L. more effective against MCF-7 by killing $87.50 \%$ cancerous cells at $1 \mathrm{mg} / \mathrm{mL}$ concentration [25]. Previous studies above consistent with this study that stigmasterol has cytotoxic activity in MCF-7 cells, although the $\mathrm{IC}_{50}$ value stigmasterol that isolated from T. flagelliforme mutant plant much lower than the stigmasterol obtained in other plants. The plants extract with $\mathrm{IC}_{50} \leq 4 \mu \mathrm{g} / \mathrm{mL}$ as the most effective crude extracts and pure compounds as cytotoxic agents against cancerous cells [26]. The $\mathrm{IC}_{50}$ value of the stigmasterol isolated from the T. flagelliforme mutant plant is $0.1623 \mu \mathrm{M}$. This value is much lower than the extract of $1.60 \mu \mathrm{g} / \mathrm{mL}$, and the ethyl acetate fraction of $1.09 \mu \mathrm{g} / \mathrm{mL}$ of the T. flagelliforme mutant plant is rational [9]. Our previous studied demonstrated that triterpenoids (pentandrucines A to K) isolated from the $n$-hexane extract of Chisocheton pentandrus is more robust cytotoxic activity against MCF-7 breast cancer cells in vitro with an $\mathrm{IC}_{50}$ value of $16.84 \mu \mathrm{M}$ than the crude extract [22].

This study indicates that a stigmasterol isolated compound from T. flagelliforme mutant compared to the crude and fraction extract is the most potent to inhibit cell proliferation on MCF-7 cell lines. Li et al. [27] reported that stigmasterol inhibits the proliferation and induced apoptotic cells in human gastric cancer cell line SNU-1 through JAK/STAT signaling pathway with an IC ${ }_{50}$ value of $15 \mu \mathrm{M}$. Stigmasterol has been clarified 
can induce apoptosis and autophagy in gastric cancer cells by blocking the Akt/mTOR signaling pathway [28]. Stigmasterol isolation from an $n$-hexane extract of Cheilanthes tenuifolia reported has $\mathrm{LC}_{50}$ value of about $205.984 \mu \mathrm{g} / \mathrm{mL}$ on shrimp nauplii. The effect of stigmasterol was isolated from Bacopa monnieri showed that the inhibition of tumor cells of EAC-bearing mice with $60.11 \%$ at $10 \mathrm{mg} / \mathrm{kg}$ [11].

Stigmasterol has been investigated for its pharmacological prospects such as antiosteoarthritic, anti-hypercholesterolemic, cytotoxicity, antitumor, hypoglycaemic, antimutagenic, antioxidant, anti-inflammatory, and CNS effects [29]. The anticancer potential of stigmasterol on various cancer has been revealed in recent times. In lung cancer, it reduces the expression of Bcl-2 as an antiapoptotic protein and enhances the BAX as a proapoptotic protein [30]. The development of skin cancer also has been suppressed by the VEGFR-2 and TNF-alpha downregulation [12], the lipid peroxide enhancement, and also by causing DNA damage [31]. The stigmasterol also induces the expression of p53 protein while inhibits the expression of p21 and p27 protein to represses prostate cancer development [33]. Furthermore, in breast cancer, stigmasterol induced growth inhibition and apoptosis in vitro in a time- and dose-dependent manner [32].

\subsection{FXR- Stigmasterol Docking}

The binding mode of stigmasterol in the FXR was investigated from its crystal structure (PDB ID: 7D42). It showed that the interactions between stigmasterol and FXR are favorable and tend to be stable. The ligand-binding site was in the center of FXR-LBD, which is around the helix-3, helix-5, helix-6, and helix-10 (Fig. 4a). It is also far from the NcoA co-regulator peptide binding site. Hence it can be assumed that there will be no alteration in the whole structure conformation of FXR-LBD. The lowest binding energy of stigmasterol-FXR is $-12.01 \mathrm{kcal} / \mathrm{mol}$, while the binding with 3-deoxy CDCA as its natural ligand results in $-11.17 \mathrm{kcal} / \mathrm{mol}$. The average RMSD value of stigmasterol conformations is lower than $2 \AA$ (Fig. 4b) which is also proved the stability of its binding with FXR.
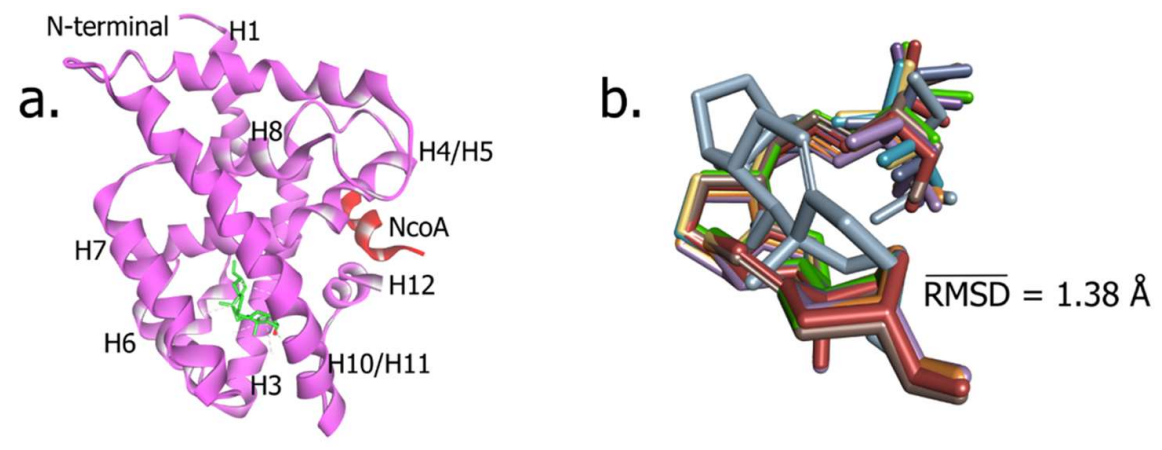

Figure 4 The 3D docking pose of stigmasterol - FXR complex. (a) The ligand-binding domain (LBD) of FXR is shown in magenta, stigmasterol is in green and the NcoA co-regulator peptide is colored red. (b) The average conformation of stigmasterol during molecular docking. The RMSD values were also calculated. The color differences represent average docking poses in 100 runs.

It is shown that the hydroxyl groups in C2 of stigmasterol formed hydrogen bonds with Thr288. The steroidal core of stigmasterol formed CH-pi interaction with Trp454, Leu287, and Ala291, while the rest of the interactions between stigmasterol and FXR was hydrophobic (Fig. 5a-b). It can be assumed that the hydrophobic interactions play a significant role in binding stability. 


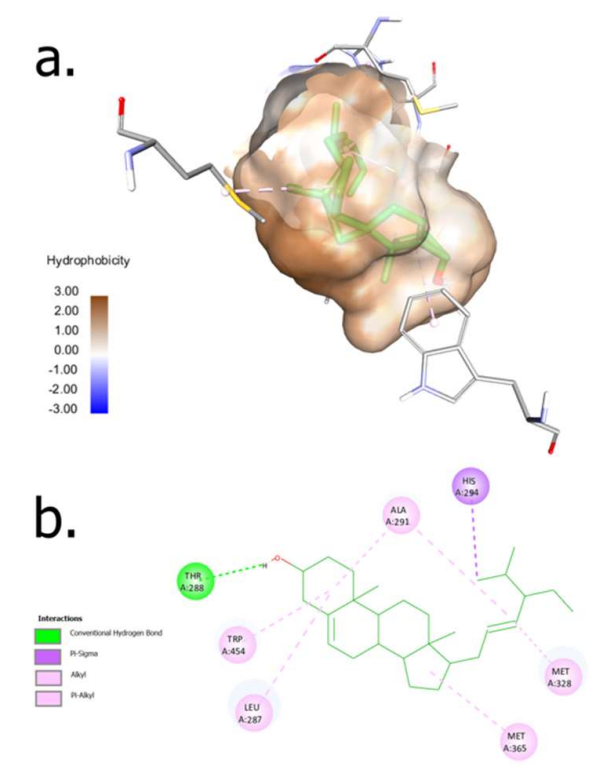

Figure 5 The ligand-receptor interactions between stigmasterol and FXR. (a) The stigmasterol as steroid ligand. (b) The 2D diagram interactions of stigmasterol-FXR was visualized using discovery studio.

As a member of the nuclear receptor superfamily, the function of FXR is to regulate bile acid homeostasis. A high level of FXR expression was detected in epithelial cells of normal and tumor breast and the invasive ductal carcinoma cells. This FXR was also present in the human breast cancer cells (MCF-7) and carcinoma cells (MDA-MB-468) [33], [34]. Moreover, in the MCF-7 cell line, FXR activation has been assumed to down-regulate breast cancer target genes such as the MRP-1, MDR3, SLC7A5, and aromatase with the inhibition of cell proliferation [34],[36]. Previous studies have also shown that the stigmasterol emerged as a potent FXR agonist in breast cancer cases [36-39]. In this work, the results from PrestoBlue Assay showed that stigmasterol could inhibit the activities of the MCF-7 cell line, which is consistent with the above findings. As displayed in Fig. 4 and 5, stigmasterol could be docked to FXR and result in high binding affinity by hydrophobic interactions. It is indicated that the steroid moiety in the structure of stigmasterol might be crucial in the binding affinity. The residues involved in stigmasterol-FXR interaction were in the ligand-binding domain [39]. This indicated that stigmasterol might act as a competitive activator with a single high-affinity binding site on FXR. These findings showed that the proper drug-like characteristics and potency cytotoxicity of stigmasterol from T. flagelliforme mutant plant were found.

\section{Conclusions}

In summary, stigmasterol isolated compound from $T$. flagelliforme mutant plant is more robust against MCF-7 breast cancer cell line in vitro with an IC50 value of $0.1623 \mu \mathrm{M}$. Stigmasterol can induce oxidative stress in MCF-7 cells that have led to apoptosis. This is facilitated by a competitive activator with a single high-affinity binding site on FXR with hydrophobic interactions. The molecular docking study showed that the interactions between stigmasterol and FXR are favorable, whereas its binding energy is lower than its natural ligand. It is postulated that the cytotoxic effect of stigmasterol towards MCF-7 cells may be due to the receptor's agonist binding sites. 
Authors Contributions: Conceptualization N.F.S., Y.E.H., K.A., and M.Y.; methodology, Y.E.H., K.A., S.S., W.D.; formal analysis, Y.E.H., K.A., S.S., W.D.; writing-review and supervision, N.F.S., Y.E.H., and M.Y.; writing-original draft preparation, K.A., and W.D.; editing, K.A.; resources the mutant plant, N.F.S., and R.P.; funding acquisition, I.G.S. All authors have read and agreed to the published version of the manuscript.

Funding: This research was supported by Bina Nusantara University as belong to research grant for lecturer.

Acknowledgments: We would like to thank the Central Laboratory of Universitas Padjadjaran, Division of Biology Activities, for providing the lab facilities, supports, and guidance.

Conflicts of Interest: The authors declare no conflict of interest.

\section{References}

1. Lai, C.S.; Mas, R.H.; Nair, N.K.; Mansor, S.M.; Navaratnam, V. Chemical constituents and in vitro anticancer activity of Typhonium flagelliforme (Araceae). Journal of Ethnopharmacology 2010, 127(2), 486-494.

2. Mohan, S.; Abdul, A.B.; Abdelwahab, S.I.; Al-Zubairi, A.; Sukari, M.; Abdullah, R.; Elhassan Taha, M.M.; Ibrahim, M.Y.; Syam, S. Typhonium flagelliforme induces apoptosis in CEMss cells via activation of caspase-9, PARP cleavage, and cytochrome c release: Its activation coupled with G0/G1 phase cell cycle arrest. J Ethnopharmacol 2010, 131, 592-600.

3. Nurrochmad, A.; Lukitaningsih, E.; Meiyanto, E. Anticancer activity of rodent tuber (Typhonium flagelliforme (Lodd.)) Blume on human breast cancer T47D cells. Int J Phytomed 2011, 2, 138-146.

4. Putra, A.; Tjahjono, Winarto. The effectiveness of Typhonium flagelliforme tuber extract of Diclorometanolic fraction on the inhibition of proliferation of MCF-7 human breast cancer cell-line. Journal of the Indonesia Medical Association 2012, 62, $10-5$.

5. Sianipar, N.F.; Purnamaningsih, R.; Gumanti, D.L.; Rosaria; Vidianty, M. Analysis of gamma irradiated fourth generation mutant of rodent tuber (Typhonium flagelliforme Lodd.) based on morphology and RAPD markers. Jurnal Teknologi 2015, 78, 41-49.

6. Sianipar, N.F.; Purnamaningsih, R.; Gumanti, D.L.; Rosaria, V.M. Analysis of gamma irradiated-third generation mutants of rodent tuber (Typhonium flagelliforme Lodd.) based on morphology, RAPD, and GC-MS markers. Pertanika Journal of Tropical Agricultural Science 2017, 40, 185-202.

7. Sianipar, N.F.; Purnamaningsih, R.; Darwati, I.; Laurent, D. Gas chromatography-mass spectrometry (GC-MS) analysis of phytochemicals of first generation gamma-irradiated Typhonium flagelliforme Lodd. Mutants. Jurnal Teknologi 2016, 78 , 1-7.

8. Sianipar, N.F.; Assidqi, K.; Purnamaningsih, R.; Herlina, T. In vitro cytotoxic activity of rodent tuber mutant plant (Typhonium flagelliforme Lodd.) against to MCF-7 breast cancer cell line. Asian J Pharm Clin Res 2019, 12, 185-189.

9. Sianipar, N.F.; Hadisaputri, Y.E.; Assidqi, K.; Simanjuntak, P.; Purnamaningsih, R. A study of anticancer activity from the fractions of rodent tuber superior mutant extract (Typhonium flagelliforme) by prestoblue assay method. Rasayan Journal of Chemistry 2020, 13(3), 1992-1998.

10. Sianipar, N.F.; Purnamaningsih, R. Enhancement of the contents of anticancer bioactive compounds in mutant clones of rodent tuber (Typhonium flagelliforme Lodd.) based on GCMS analysis. Pertanika J Trop Agric Sci 2018, 41, 305-320.

11. Ghosh, T.; Maity, T.K.; Singh, J. Evaluation of antitumor activity of stigmasterol, a constituent isolated from Bacopa monnieri Linn aerial parts against Ehrlich Ascites Carcinoma in mice. Orient Pharm Exp Med 2011, 11, 41-49.

12. Kangsamaksin, T.; Chaithongyot, S.; Wootthichairarangsan, C.; Hanchaina, R.; Tangshewinsirikul, C.; Svasti, J. Lupeol and stigmasterol suppress tumor angiogenesis and inhibit cholangiocarcinoma growth in mice via downregulation of tumor necrosis factor-a. PLoS ONE 2017, 12(12), 1-16.

13. Bae, H.; Song, G.; Lim, W. Stigmasterol causes ovarian cancer cell apoptosis by inducing endoplasmic reticulum and mitochondrial dysfunction. Pharmaceutics 2020, 12, 1-16.

14. Rosdi, M.N.M.; Arif, S.M.; Abu Bakar, M.H.; Razali, S.A.; Zulkifli, R.M.; Ya'akob, H. Molecular docking studies of bioactive compounds from Annona muricata Linn as potential inhibitors for Bcl-2, Bcl-w and Mcl-1 anti-apoptotic proteins. Apoptosis 2018, 23, 27-40. DOI: 10.1007/s10495-017-1434-7.

15. Biswal, A.R.; Pazhamalai, V.; Romauld, I.S.; Molecular docking of various bioactive compounds from essential oil of 
Trachyaspermum ammi against the fungal enzyme Candidapepsin-1. J. Appl. Pharm. Sci. 2019, 9, 21-032. DOI: 10.7324/JAPS.2019.90503.

16. George, T.K.; Tomy, A.; Jisha, M.S. Molecular Docking Study of Bioactive Compounds of Withania somnifera Extract Against Topoisomerase IV Type B. Proc. Natl. Acad. Sci. India Sect. B - Biol. Sci. 2020, 90, 381-390. DOI: 10.1007/s40011-01901110-z.

17. Guedes, I.A.; de Magalhaes, C.S.; Dardenne L.E. Receptor-ligand molecular docking. Biophys Rev 2014, 6, 75-87. DOI: https://doi.org/10.1007/s12551-013-0130-2

18. Jiang, L.; Xiao, D.; Li, Y.; Dai, S.; Qu, L.; Chen, X.; Chen, X.; Guo, M.; Wei, H.; Chen, Y. Structural basis of tropifexor as a potent and selective agonist of farnesoid X receptor," Biochem. Biophys. Res. Commun. 2021, 534, 1047-1052. DOI: 10.1016/j.bbrc.2020.10.039.

19. Mi, L.; Devarakonda, S.; Harp, J.M.; Han, Q.; Pellicciari, R.; Willson, T.M.; Khorasanizadeh, S.; Rastinejad, F. Structural Basis for Bile Acid Binding and Activation of the Nuclear Receptor FXR University of Virginia Health System. Mol. Cell 2003, 11, 1093-1100.

20. Morris, G.M.; Huey, R.; Lindstrom, W.; Sanner, M.F.; Bellew, R.K.; Goodsell, D.S.; Olson, J.A. Software news and updates AutoDock4 and AutoDockTools4: Automated docking with selective receptor flexibility. J. Comput. Chem. 2009, 30, 27852791. DOI: $10.1002 /$ jcc. 21256.

21. Supriadi, H., Salam, S., Abdullah, F.F., Subarnas, A., Sidik, R., Supratman1, U., Shiono Y. Steroids from the Super Red Dragon Fruit (Hylocereus costaricensis). Journal of Chemistry 2019, 13(2), 229-233. DOI: 10.24843/JCHEM.2019.v13.i02.p17

22. Salam, S., Harneti, D., Maharani, R, Nurlelasari, Safari, A., Hidayat, A.T., Lesmana, R., Nafiah, M.A., Supratman, U., Prescott, T.A.K., Shiono, Y. Cytotoxic triterpenoids from Chisocheton pentandrus. Phytochemistry 2021, 187, 1-12. DOI: 10.1016/j.phytochem.2021.112759

23. Al-Fatlawi, A.A.Y. Stigmasterol inhibits proliferation of cancer cells via apoptotic regulatory genes. Bioscience Research 2019, 16(1), 695-702.

24. Shan, L.Y.; Thing, T.C.; Ping, T.S.; Awang, K.; Hashim, N.M.; Nafiah, M.A.; Ahmad, K. Cytotoxic, antibacterial and antioxidant activity of triterpenoids from Kopsia singapurensis Ridl. Journal of Chemical and Pharmaceutical Research 2014, 6(5), 815822.

25. Ayaz, M.; Sadiq, A.; Wadood, A.; Junaid, M.; Ullah, F.; Khan, N.Z. Cytotoxicity and molecular docking studies on Phytosterols isolated from Polygonum hydropiper L. Stereoid 2019, 141, 30-35. DOI: 10.1016/j.steroids.2018.11.005

26. Dehghan-Nayeri, N.; Darvishi, M.; Mashati, P.; Rezapor-Kalkhoran, M.; Rezaiefard, M.; Younesian, S. Comparison of cytotoxic activity of herbal extracts on the most commonly used breast cancer cell lines (MCF7 and SKBR3): A systematic review. Journal Research in Pharmacy 2020, 24(1), 1-22. DOI: 10.35333/jrp.2020.121

27. Li, K.; Yuan, D.; Yan, R.; Meng, L.; Zhang, Y.; Zhu, K. Stigmasterol exhibits potent antitumor effects in human gastric cancer cells mediated via inhibition pf cell migration, cell cycle arrest, mitochondrial mediated apotosis and inhibition of JAK/STAT signalling pathway. JBUON 2018, 23(5), 1420-1425.

28. Zhao, H.; Zhang, X.; Wang, X.; Lin, Y.; Zhou, S. Stigmasterol simultaneously induces apoptosis and protective autophagy by inhibiting Akt/mTOR pathway in gastric cancer cells. Frontiers in Oncology 2021, 11, 1-11. DOI: 10.3389/fonc.2021.629008

29. Kaur, N.; Chaudhary, J.; Akash, J.; Kishore, L. Stigmasterol: A comprehensive review. Int. J. Pharm. Sci. Res. 2011, 2, 22592265.

30. Kanipandian, N.; Li, D.; Kannan, S. Induction of an intrinsic apoptotic signaling pathway in A549 lung cancer cells using silver nanoparticles from Gossypium hirsutum and evaluation of in vivo toxicity. Biotechnol. Reports 2019, 23, 1-11. DOI: 10.1016/j.btre.2019.e00339.

31. Ali, H.; Dixit, S.; Ali, D.; Alqahtani, S.M.; Alkahtani, S.; Alarifi, S. Isolation and evaluation of anticancer efficacy stigmasterol in a mouse model of DMBA-induced skin carcinoma. Drug Des. Devel. Ther. 2015, 9, 2793-2800.

32. Scholtysek, C.; Krukiewicz A.A.; Alonso, J.L.; Sharma, K.P.; Sharma, P.C.; Goldmann, W.H. Characterizing components of the Saw Palmetto Berry Extract (SPBE) on prostate cancer cell growth and traction. Biochem. Biophys. Res. Commun. 2009, 379, 795-798. DOI: 10.1016/j.bbrc.2008.11.114.

33. Bolaños-Carrillo, M.A.; Ventura-Gallegos, J.L.; Saldivar-Jiménez, A.D.; Zentella-Dehesa, A.; Martínez-Vázquez, M. Effect of Sterols Isolated from Myrtillocactus geometrizans on Growth Inhibition of Colon and Breast Cancer Cells. Evidence-based Complement. Altern. Med. 2015, 2015, 1-9. DOI: 10.1155/2015/589350.

34. Swales, K.E.; Korbonits, M.; Carpenter, R.; Walsh, D.T.; Warner, T.D.; Bishop-Bailey, D. The farnesoid X receptor is expressed in breast cancer and regulates apoptosis and aromatase expression. Cancer Res. 2006, 66, 10120-10126. DOI: 10.1158/0008-5472.CAN-06-2399.

35. Wang, Y.D.; Chen, W.D.; Moore, D.D.; Huang, W. FXR: A metabolic regulator and cell protector. Cell Res. 2008, 18, 10871095. DOI: $10.1038 /$ cr.2008.289.

36. Giordano, C.; Catalano, S.; Panza, S.; Vizza, D.; Barone,I.; Bonofiglio, D.; Gelsomino, L.; Rizza, P.; Fuqua, S.W.; Ando, S. Farnesoid $\mathrm{X}$ receptor inhibits tamoxifen-resistant MCF-7 breast cancer cell growth through downregulation of HER2 expression. Oncogene 2011, 30, 4129-4140. DOI: 10.1038/onc.2011.124. 
37. Journe, F.; Laurent, G.; Chaboteaux, C.; Nonclercq, D.; Durbecq, V.; Larsimont, D.; Body, J. Farnesol, a mevalonate pathway intermediate, stimulates MCF-7 breast cancer cell growth through farnesoid-X-receptor-mediated estrogen receptor activation. Breast Cancer Res. Treat. 2007, 107, 49-61. DOI: 10.1007/s10549-007-9535-6.

38. Giordano, C.; Barone, I.; Vircillo, V.; Panza, S.; Malivindi, R.; Gelsomino, L.; Pellegrino, M.; Rago, V.; Mauro, L.; Lanzino, M.; Panno, M.L.; Bonofiglio, D.; Catalano, S.; Ando, S. Activated FXR Inhibits Leptin Signaling and Counteracts Tumorpromoting Activities of Cancer-Associated Fibroblasts in Breast Malignancy. Sci. Rep. 2016, 6, 1-13. DOI: 10.1038/srep21782.

39. Jiang, L.; Zhang, H.; Xiao, D.; Wei, H.; Chen, Y. Farnesoid X receptor (FXR): Structures and ligands. Computational and Structural Biotechnology Journal 2021, 19, 2148-2159. DOI: 10.1016/j.csbj.2021.04.029. 